\title{
An Estimation of the Incidence and Demographic Picture of the Major Hemoglobinopathies in Belgium (From a Confidential Inquiry)
}

Béatrice Gulbis, Alice Ferster, Christiane Vermylen, Marie-Françoise Dresse, Anna Vanderfaeillie, André Delannoy, Veerle Labarque, Pierre Philippet, Alain Kentos, Bernard Sztern, Bernard Deprijck \& Françoise Vertongen (for the "Red Blood Cell Disorders Subcommittee" of the Belgian Haematological Society)

To cite this article: Béatrice Gulbis, Alice Ferster, Christiane Vermylen, Marie-Françoise Dresse, Anna Vanderfaeillie, André Delannoy, Veerle Labarque, Pierre Philippet, Alain Kentos, Bernard Sztern, Bernard Deprijck \& Françoise Vertongen (for the "Red Blood Cell Disorders Subcommittee" of the Belgian Haematological Society) (2008) An Estimation of the Incidence and Demographic Picture of the Major Hemoglobinopathies in Belgium (From a Confidential Inquiry), Hemoglobin, 32:3, 279-285, DOI: 10.1080/03630260802004400

To link to this article: http://dx.doi.org/10.1080/03630260802004400

Published online: 07 Jul 2009.

Submit your article to this journal $₫$

山 Article views: 12

Q

View related articles $\widetilde{\nearrow}$

Citing articles: 1 View citing articles $ک$ 


\title{
AN ESTIMATION OF THE INCIDENCE AND DEMOGRAPHIC PICTURE OF THE MAJOR HEMOGLOBINOPATHIES IN BELGIUM (FROM A CONFIDENTIAL INQUIRY)
}

\author{
Béatrice Gulbis, ${ }^{1}$ Alice Ferster, ${ }^{2}$ Christiane Vermylen, ${ }^{3}$ \\ Marie-Françoise Dresse, ${ }^{4}$ Anna Vanderfaeillie, ${ }^{5}$ André Delannoy, ${ }^{6}$ \\ Veerle Labarque, ${ }^{7}$ Pierre Philippet, ${ }^{8}$ Alain Kentos, ${ }^{9}$ Bernard Sztern, ${ }^{10}$ \\ Bernard Deprijck, ${ }^{11}$ and Françoise Vertongen" (for the "Red Blood Cell \\ Disorders Subcommittee" of the Belgian Haematological Society) \\ ${ }^{1}$ Department of Clinical Chemistry, Cliniques Universitaires de Bruxelles, Hôpital Erasme, \\ Université Libre de Bruxelles, Bruxelles, Belgium \\ ${ }^{2}$ Department of Paediatric Haematology and Oncology, Hôpital Universitaire des Enfants \\ Reine Fabiola, Université Libre de Bruxelles, Bruxelles, Belgium \\ ${ }^{3}$ Department of Paediatric Haematology and Oncology, Cliniques Universitaires Saint-Luc, \\ Université Catholique de Louvain, Bruxelles, Belgium \\ ${ }^{4}$ Department of Paediatrics, CHR de la Citadelle, Université de Liège, Liège, Belgium \\ ${ }^{5}$ Department of Paediatrics, CHU Saint-Pierre, Université Libre de Bruxelles, Bruxelles, \\ Belgium \\ ${ }^{6}$ Department of Haematology, Cliniques Universitaires Saint Luc, Université Catholique \\ de Louvain, Bruxelles, Belgium \\ ${ }^{7}$ Department of Paediatrics, Universitaire Ziekenhuizen Katholieke Universiteit Leuven, \\ Leuven, Belgium \\ ${ }^{8}$ Department of Paediatrics, Clinique de l'Espérance, Montegnée, Belgium \\ ${ }^{9}$ Department of Medicine, Cliniques Universitaires de Bruxelles, Hôpital Erasme, Université \\ Libre de Bruxelles, Bruxelles, Belgium \\ ${ }^{10}$ Department of Medicine, Hôpitaux IRIS Sud, Site Molière-Longchamps, Bruxelles, Belgium \\ ${ }^{11}$ Department of Medicine, Division of Hematology, University of Liège, Liège, Belgium
}

$\square \quad$ An estimation of the incidence and demographic picture of the major hemoglobinopathies in Belgium has been approached through a confidential inquiry sent to 228 pediatric and adult

Received 22 May 2007; accepted 30 June 2007.

Address correspondence to Professor Béatrice Gulbis, Laboratory of Clinical Chemistry, C.U.B. Hôpital Erasme, Route de Lennik 808, Brussels 1070, Belgium; Tel.: +33-2-555-34-27; Fax: +32-3-555-66-55; E-mail: bgulbis@ulb.ac.be 
hematological departments. Forty-two percent of responses showed that 417 patients are known in Belgium: $83 \%$ with sickle cell disease, $13 \%$ with $\beta$-thalassemia ( $\beta$-thal) major, $2 \%$ with $\beta$-thal intermedia, and $1 \%$ with $\mathrm{Hb} H$ disease. Twenty-five percent of the sickle cell disease patients and $54 \%$ of those suffering from a $\beta$-thal major were older than 20 years. Three hospitals ensure the follow-up of $70 \%$ of the patients and are situated in Brussels, Belgium; a follow-up of less than 20 patients was reported at 21 centers. These results confirm that sickle cell disease is the major hemoglobinopathy in Belgium; it concerns mostly pediatricians but adult hematologists are also confronted with these pathologies. Therefore, it is necessary to implement integrated programs of prevention and treatment.

Keywords Sickle cell disease/disorder(s), Thalassemia, Incidence, Europe

\section{INTRODUCTION}

Hemoglobinopathies are recessively inherited blood disorders; they occur more frequently in populations where malaria was or is endemic (1). This is the reason why these disorders are rarely encountered in indigenous North and West European populations. Nowadays, European populations are a mixture of individuals from various ethnic origins but the number of individuals originating from a country at-risk for a hemoglobinopathy is increasing (2). In this context, global health care has been implemented in the United Kingdom and France, where hemoglobinopathies are encountered with a high incidence $(3,4)$; it includes neonatal and, in the UK, antenatal national prevention programs.

In The Netherlands, many publications have shown that hemoglobinopathies are a serious global health problem in that country, where a high level of immigration is reported (5-7). Belgium has the same need for a prevention policy towards hemoglobinopathies. Estimating prevalence of carriers and annual affected births can be obtained for Belgium and were recently published (2), but the real incidence of these disorders has only been reported for Brussels since a systematic neonatal screening for hemoglobinopathies has only been conducted in that city since 1994 (8). The purpose of the present study was to estimate the number of patients suffering from a major hemoglobinopathy, who have regular follow-up examinations, and thus to evaluate the need for the implementation of an integrated strategy for hemoglobinopathies prevention, diagnosis and treatment in Belgium.

\section{MATERIALS AND METHODS}

In November 2005 and in May 2006, all the Belgian adult internal medicine and pediatric departments $(n=228)$ received a letter explaining the health problem of hemoglobinopathies and asking for a report on their patients suffering from a major hemoglobinopathy. They were asked to respond even if no patient was followed in their department. 
The anonymous inquiry asked for the birth date and sex of each patient regularly followed and suffering from a sickle cell disorder [i.e., $\mathrm{Hb} \mathrm{SS}, \mathrm{Hb}$ $\mathrm{SC}, \mathrm{Hb} \mathrm{S} / \beta$-thalassemia ( $\beta$-thal) or another type], a $\beta$-thal major or intermedia, or a $\mathrm{Hb} \mathrm{H}$ disease. It also asked if a specific therapy was given to their patients (hydroxyurea, transfusion, or bone marrow transplant), and if their geographic origin was known.

\section{RESULTS}

Forty-two percent $(96 / 228)$ responses were received. Except for the province of Luxembourg (where one response from five centers was received), more than $37 \%$ responses were received from each of the other eight Belgian provinces. No patients, less than five patients and between five and 20 patients were followed in 71, 11 and 10 departments, respectively. Four centers reported more than 20 patients. After discarding double registrations, 417 patients suffering from a severe hemoglobinopathy were reported (Table 1). Of these, 346 were sickle cell disease patients, 56 were affected by a $\beta$-thal major, 10 by a $\beta$-thal intermedia and five by $\mathrm{Hb} \mathrm{H}$ disease. The sickle cell disease group of patients was composed of $319 \mathrm{Hb}$ $\mathrm{SS}, 13 \mathrm{Hb} \mathrm{SC}$ disease, $13 \mathrm{Hb} \mathrm{S} / \beta$-thal, and one $\mathrm{Hb} \mathrm{SD}$ patient. Three Brussels centers ensure the follow-up of $293 / 417$ patients $(70 \%)$.

The age range within the two major groups of patients, i.e., sickle cell disease and $\beta$-thal major, is represented in Figure 1 . The majority $(75 \%)$ of sickle cell disease patients were younger than 21 years old, while more than a half $(54 \%)$ of the patients suffering from a $\beta$-thal major, were older than 20 years. The sex ratio was $1: 1$.

No specific therapy was given to $15 \%$ of the $\mathrm{Hb}$ SS (46/316; median age 6 vs. 14 years old for those receiving a specific therapy) and $\mathrm{Hb} \mathrm{S} / \beta$-thal cases (2/13), $46 \%$ of the $\mathrm{Hb}$ SC disease cases (6/13; median age 3 vs. 17 years old for those receiving a specific therapy), $56 \%$ of the $\beta$-thal intermedia (5/9; median age 9 vs. 34 years old for those receiving a specific

TABLE 1 Distribution of Patients by Hemoglobinopathy

\begin{tabular}{lrrr}
\hline & & \multicolumn{2}{c}{ Age (years) } \\
\cline { 3 - 4 } Hemoglobin Disorders & $n$ & Median & Range \\
\hline Hb SS & 319 & 13.0 & $1-47$ \\
Hb SC & 13 & 7.0 & $1-53$ \\
Hb S/ $\beta$-thal & 13 & 15.0 & $5-49$ \\
Hb SD & 1 & 19.0 & - \\
$\beta$-Thal major & 56 & 22.0 & $1-42$ \\
$\beta$-Thal intermedia & 10 & 12.5 & $2-37$ \\
Hb H disease & 5 & 13.0 & $10-29$ \\
\hline
\end{tabular}




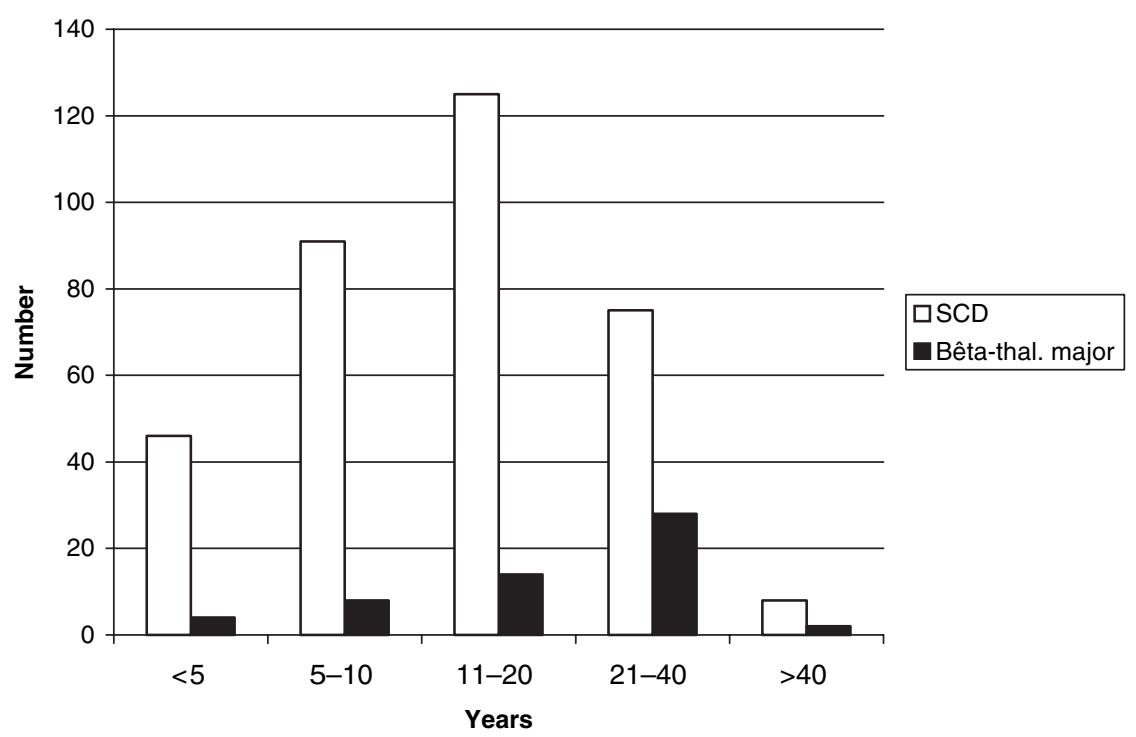

FIGURE 1 Age distribution of the patients reported with a sickle cell disorder or a $\beta$-thal major.

therapy) and $100 \%$ of the $\mathrm{Hb} \mathrm{H}$ disease cases. All patients suffering from a $\beta$-thal major received a specific treatment.

The geographic ancestry origin was reported for 142 patients. The main geographic ancestry origin was Sub-Saharan Africa for sickle cell disease patients $(81 / 93 ; 88 \%)$, the Mediterranean Basin for the patients affected by a $\beta$-thal major or intermedia $(37 / 45 ; 82 \%)$, and Asia for $\mathrm{Hb} \mathrm{H}$ disease patients $(5 / 5 ; 100 \%)$.

\section{DISCUSSION}

With a $42 \%$ response and a well distributed level of response within each of the nine Belgian provinces, and considering a certain level of underestimation, it might be established that in a Belgian population of around 10 millions inhabitants, at least 500 patients are being followed for a hemoglobinopathy and that there is an increasing prominence of sickle cell disorders. The Belgian Cystic Fibrosis Registry reported 860 living patients in 2003, implying that hemoglobinopathies are now as significant as cystic fibrosis in their contribution to inherited disorders in this country; the same conclusion was previously given for all of Europe $(9,10)$.

These results are concordant with those obtained through the systematic neonatal screening for hemoglobinopathies in Brussels, as it had been demonstrated that in a population of more than 100,000 newborns screened, the incidence of sickle cell disorders was around 1:2,000, of $\beta$-thal major was around 1:20,000, and of $\mathrm{Hb} \mathrm{H}$ disease was around 1:40,000 (8). 
It is also interesting to find that the same picture was observed in The Netherlands in 2002: among 16 million inhabitants, at least 700 patients were followed for a sickle cell disorder and 100 for a $\beta$-thal major anomaly (7). Recent publications have also confirmed the prominence of sickle cell disorders in the UK $(2)$ and France $(4,11)$. One must be aware that these numbers will probably continue to increase in North and West European countries since most migrants are young, have a high birth rate and frequently, consanguineous marriages; on the other hand, a falling general birth rate compared to European indigenous populations will probably contribute to a decrease in the incidence of hemoglobinopathies in Southern Europe (2).

Our results demonstrated that with a median age of 13 years old, sickle cell disease concerned mostly pediatricians. However, with $25 \%$ of patients older than 21 years and the increase in life expectancy, it is also of importance to take into account adult patients, and more specifically, pregnancy.

In the Dutch inquiry, it was reported that almost half the patients affected with sickle cell disease were older than 15 years. That difference with our results might be attributed to an increase of immigration in the last few years in The Netherlands (12). Another explanation might be related to the fact that a systematic neonatal screening for hemoglobinopathies was implemented only at the start of 2007 in The Netherlands. Indeed, among the 96 sickle cell disease patients reported by the Brussels centers and who are younger than 10 years of age, 80 were detected by the Brussels systematic neonatal screening, which implies a very early diagnosis and follow-up.

Another crucial aspect is the variable number of patients followed in a center. The Dutch inquiry revealed the same picture: patients are concentrated in large cities (7). The heterogeneous distribution of patients with a rare disease should encourage the development of a partnership with health care professionals and patients' associations. Belgium has seen the creation of a health care professional group within the Belgian hematological society (http://www.bhs.be/). The aims are mainly focused on national recommendations for prevention, diagnosis and management of hemoglobinopathies, and the creation of a patient database.

Various strategies have been applied in Europe (2), but there is often still a lack of awareness among health authorities. It is probably time to work together and to integrate the existing European dedicated networks like the new "EuroMediterranean Network of Research Centres Conducting Molecular and Clinical Research of Thalassaemia and Related Haemoglobinopathies" (http://www.ithanet.eu) and the "European Network for Rare and Congenital Anaemias" (http://www.enerca.org).

The main geographic origins of the patients were those expected for the diagnosed disorders, but we are now facing couples of different ethnic 
origins who are at-risk for combined hemoglobinopathies. Some ethnic groups are poorly represented in this country and there might be an almost complete lack of awareness among health care workers about specific hemoglobinopathies.

\section{CONCLUSIONS}

Population movement within Europe or from other countries where people are at risk for hemoglobin disorders have increased during these last few decades. Europe, from the North to the West, is facing more and more affected births, and sickle cell disorders represent the major part of the hemoglobinopathies encountered; to date, more affected children are born in the immigration areas of Northern Europe than in the original endemic countries of Southern Europe. Although rare, these disorders now represent a significant health problem in Europe, and epidemiological data are good for assessing needed health care.

\section{ACKNOWLEDGMENTS}

The authors thank all the contributors for their participation in this inquiry. The study was supported by the European Commission (EC) through its Public Health and Consumer Protection Directorate (DG SANCO), Executive Agency for the Public Health Programme.

\section{REFERENCES}

1. Livingstone FB. Malaria and human polymorphisms. Ann Rev Genet 1971; 5:33-38.

2. Modell B, Darlison M, Birgens H, Cario H, Faustino P, Giordano PC, Gulbis B, Hopmeier P, LenaRusso D, Romao L, Theodorsson E. Epidemiology of haemoglobin disorders in Europe: an overview. Scand J Clin Lab Invest 2007; 67(1):39-69.

3. Davies SC, Cronin E, Gill M, Hickman M, Normand D. Screening for sickle cell disease and thalassaemia: a systematic review with supplementary research. Health Technol Assess 2000; 4(3):1-99.

4. Bardakjian-Michau J. Neonatal detection of sickle cell disease. J Gynecol Obstet Biol Reprod (Paris) 2003; 32(Suppl 1):1S61-1S64.

5. Giordano PC, Harteveld CL. Prevention of hereditary haemoglobinopathies in The Netherlands. Ned Tijdschr Geneeskd 2006; 150(39):2137-2141.

6. Giordano PC, Plancke A, Van Meir CA, Janssen CA, Kok PJ, Van Rooijen-Nijdam IH, Tanis BC, van Huisseling JC, Versteegh FG. Carrier diagnostics and prevention of hemoglobinopathies in early pregnancy in The Netherlands: a pilot study. Prenat Diagn 2006; 26(8):719-724.

7. Giordano PC, Bouva MJ, Harteveld CL. A confidential inquiry estimating the number of patients affected with sickle cell disease and thalassemia major confirms the need for a prevention strategy in The Netherlands. Hemoglobin 2004; 28(4):287-296.

8. Gulbis B, Ferster A, Cotton F, Lebouchard MP, Cochaux P, Vertongen F. Neonatal haemoglobinopathy screening: review of a 10-year programme in Brussels. J Med Screen 2006; $13(2): 76-78$.

9. http://www.ecfs.eu/ECFRegistry/AnnualECFRegistryReports.htm 
10. World Health Organization. The molecular genetic epidemiology of cystic fibrosis. Report of a joint meeting of WHO/ECFTN/ICF/(M)A/A/ECFS. Genoa, Italy, June 2002. WHO/HGN/CF/ WG/04.02.

11. Badens C, North ML, Lena-Russo D. $\beta$ Thalassemia in Metropolitan France. Press Med 2003; 32(22):1016-1021.

12. Giordano PC, Dihal AA, Harteveld CL. Estimating the attitude of immigrants toward primary prevention of the hemoglobinopathies. Prenat Diagn 2005; 25(10):885-893. 
